\title{
SAVING THE LOST SHEEP OF THE HOUSE OF ISRAEL: PURITY, FORGIVENESS, AND SYNAGOGUES IN THE GOSPEL OF MATTHEW
}

\author{
Anders Runesson*
}

\begin{abstract}
It is commonplace in New Testament studies to point out that ancient writings need to be understood within their contemporary context if a historical reading is what we aim for. Most often, however, the framework within which to understand a text's thought patterns is sought in the world of ideas that can be found in other literary texts roughly contemporaneous with the text under investigation. It is far less common for scholars to provide a detailed analysis of the institutions of ancient societies in which the transmission of oral traditions and the production of texts were embedded, and allow this socio-institutional setting to interpret the thought patterns of a text. In this study, key ritual-theological themes in Matthew's narrative world are linked to, and understood from within, first-century synagogue institutions. As a result, Matthew's theology of purity, forgiveness, and atonement emerge as thoroughly intertwined with a first-century Jewish worldview rather foreign to later forms of mainstream Christianity.
\end{abstract}

\section{Introduction: Reading Matthew in Institutional Settings}

While no one would contest the fact that Jesus visited and proclaimed his message in the synagogues of primarily Galilee but also of Judaea, it is rare to see studies that seriously ponder the socio-political and religious implications of this institutional setting for our understanding of his message. Indeed, when scholars speak of the early Jesus movement and the Gospels it is not uncommon that they assume the existence of not one but two distinct institutional contexts, one associated with Judaism ("synagogue") and the other associated with Christianity ("church"), as if these two existed as separate entities in the first century. ${ }^{1}$ Such use of terminology reflects assumptions about the New Testament texts in relation to Jews and Judaism that construes, implicitly or explicitly, "Judaism" and "Christianity," as we know them today, as two distinct religious movements already at this time.

\footnotetext{
* Associate Professor, Department of Religious Studies at McMaster University, Canada. Email: runess@mcmaster.ca

${ }^{1}$ For terminological problems relating to Jews and (Jewish and non-Jewish) Christ-believers in the first century, see discussion in Anders Runesson, "Inventing Christian Identity: Paul, Ignatius, and Theodosius I," in Exploring Early Christian Identity, ed. Bengt Holmberg (Tübingen: Mohr Siebeck, 2008), 62-74; Anders Runesson, "Paul's Judaism: The Architecture of Contemporary Discussions," in Paul within Judaism: Restoring the First-Century Context to the Apostle, eds. Mark Nanos and Magnus Zetterholm (Minneapolis: Fortress, 2015), 53-77. For a full discussion of the use of the term ekklēsia in antiquity, see Ralph Korner, "Before 'Church': Political, Ethno-Religious and Theological Implications of the Collective Designation of Pauline Christ-Followers as Ekklēsiai" (Ph.D thesis, McMaster University, 2014). In the first century, ekklēsia, often erroneously translated "church," was a term used for a variety of Graeco-Roman and Jewish institutions, and its use in Paul's letters or in Matthew's Gospel, for example, can therefore not be referred to in order to suggest a "parting of the ways between Judaism and Christianity," since it is not a term indicating, as "church" does, an institutional setting exclusively meant for Christ-believers. See further discussion below.
} 
In this study I would like to discuss how recent research on the ancient synagogue may shed light not only on questions relating to the so-called parting of the ways between Judaism and Christianity, but also on theological themes central to Christian theology, such as eschatology, holiness, and forgiveness. Doing so, it will become apparent that these theological themes, so important for Christian identity, can hardly be understood apart from their Jewish context. In order to show this, we shall focus on Matthew's Gospel and proceed in two main steps. First, we shall discuss the nature of first-century synagogues. As we shall see, behind the twenty-five Greek, Hebrew, and Latin terms used in antiquity to designate what we translate into English with one single word as "synagogue" lie two types of institution, neither of which is identical to the later Rabbinic synagogue which gave birth to all modern mainstream forms of Judaism.

This distinction between two types of institution, which is of key importance for our understanding of first-century Jewish society, will then function as the point of departure for the second part of the study, in which we shall enter into Matthew's narrative world and discuss how institutional structures described there may shed light on the thought patterns of the Gospel. In other words, in order to understand first-century portrayals of interaction between followers of Jesus and other Jews, as well as the theological constructs that were produced as a result of this interaction, we need to move beyond anachronistic assumptions about later Rabbinic and Christian institutional forms and seek to untangle the complexities of a world which is not ours, but in which most of the New Testament texts - texts that are still used today - were written.

\section{Beyond the Rabbis: The Nature of First-Century Synagogues}

What was a synagogue in the time of Jesus? Or when the Gospels were written? How do we understand the word "synagogue" when we read it in the New Testament? Perhaps the easiest way of defining and explaining the nature of the ancient synagogue is by contrasting a modern synagogue and the activities taking place within it with the city hall of any given city.

The synagogue as a public municipal institution, a religio-political city hall of sorts, is the most common type of synagogue referred to in the New Testament Gospels. ${ }^{2}$ The modern synagogue has very little in common with the activities that took place in such ancient public institutions, apart from some liturgical aspects which have been maintained in relation to sabbath services. The modern synagogue goes back to the Rabbis, and rabbinic Judaism did not exist in Jesus' time, or at the time when the Gospels were written. ${ }^{3}$ This public institution, we may call it the public synagogue, in which Jesus

\footnotetext{
${ }^{2}$ For discussion of the synagogue as it is represented in the New Testament Gospels and in relation to historicalJesus research, see Anders Runesson, "The Historical Jesus, the Gospels, and First-Century Jewish Society: The Importance of the Synagogue for Understanding the New Testament," in A City Set on a Hill: Essays in Honour of James F. Strange, eds. Daniel A. Warner and Donald D. Binder (Mountain Home, AR: BorderStone Press, LLC, 2014), 265-297.

${ }^{3}$ Rabbinic Judaism was born at some point after the fall of the temple in $70 \mathrm{CE}$, i.e., around the same time as the Gospels were written. However, just as Apostolic, or Messianic, Judaism (for terminology, see Runesson, "Inventing Christian Identity," 72-73, and the chart on page 74) was a minority form of Judaism at that time, Rabbinic Judaism was a marginal movement with no interest in the synagogue. Local public synagogues were run by local authorities, often of priestly descent. For discussion of the lack of Rabbinic influence in ancient synagogues, and issues relating to leadership more generally, see, e.g., Lee Levine, The Ancient Synagogue: The First Thousand Years (New Haven: Yale
} 
taught, healed, and exorcized demons according to the Gospels, was the administrative centre of towns and villages in Galilee and Judaea. It had its origins in the city gates of Persian Period Yehud; these gates were, at the time, the local public space providing a home for the administrative and other activities, including public Torah reading, that later took place in public synagogues in the first century. ${ }^{4}$ In these public synagogues decisions were made regarding all things local; archives were kept there, judicial proceedings took place there, and since, in antiquity, people did not distinguish between the secular and the religious, the Torah was read and discussed publicly on Sabbaths.

Architecturally, the closest modern analogy to the public synagogue would probably be the British Parliament. This type of architecture was made for interaction: discussion and debate. The focal point of the building was not, as in most modern synagogues and churches, on an item placed at one of the walls (like a Torah shrine or an altar), but on the empty centre in the middle of the room from where, on Sabbaths, the Torah was read. ${ }^{5}$

It is of some interest to note that both men and women were present in meetings held in this institution; such gender inclusivity departs from the more general pattern in Graeco-Roman societies, in which only men were allowed to attend public meetings. As for leadership, no specific Jewish group, such as the Pharisees, ${ }^{6}$ was in charge, but village scribes were leading figures. While anyone who was able could read portions from, and participate in discussions of, the Torah on Sabbaths, the scribes most likely dominated the interpretation of the texts. ${ }^{7}$ These scribes could be influenced in their understanding of Torah and Jewish life by groups such as the Pharisees, or the Jesus movement, but we may safely assume that local traditions were more important than the Jewish parties for the interpretation of the law, at least in the rural areas of Galilee. ${ }^{8}$

Despite this emphasis on the local, however, it seems clear that there were also some aspects of the law that were generally agreed upon. Most importantly, as is shown by the ritual baths (miqwaoth) and the stone vessels found all over the land, ritual purity was a

University Press, 2005), 412-529. See also Lee Levine, "The Sages and the Synagogue in Late Antiquity," in The Galilee in Late Antiquity, ed. Lee I. Levine (New York: The Jewish Theological Seminary of America, 1992), 201-224; Shaye J.D. Cohen, "The Place of the Rabbi in Jewish Society," in The Galilee in Late Antiquity, ed. Lee I. Levine (New York: The Jewish Theological Seminary of America, 1992), 157-173; Günter Stemberger, Jews and Christians in the Holy land: Palestine in the Fourth Century (Edinburgh: T \& T Clark, 2000), 121-160, and esp. pages 277-283. Cf. Chad S. Spigel, Ancient Synagogue Seating Capacities: Methodology: Analysis and Limits (Tübingen: Mohr Siebeck, 2012), who notes, and agrees with, the growing consensus that "rabbis did not have significant influence over synagogue worship prior to the medieval period" (3).

${ }^{4}$ For extensive discussion of the evidence and various theoretical approaches to origins questions, see Anders Runesson, The Origins of the Synagogue: A Socio-Historical Study (ConBNT 37; Stockholm: Almqvist \& Wiksell International, 2001).

${ }^{5}$ For discussion of synagogue architecture, including viewshed analysis, see James F. Strange, "Archaeology and Ancient Synagogues up to about 200 CE," in The Ancient Synagogue: From its Origins until 200 CE, eds. Birger Olsson and Magnus Zetterholm (Stockholm: Almqvist \& Wiksell International, 2003), 37-62.

${ }^{6}$ Cf. Levine, The Ancient Synagogue, 41: "[T] $]$ he truth of the matter is, the Pharisees had little or nothing to do with the early synagogue, and there is not one shred of evidence pointing to a connection between the two. No references associate the early Pharisees (the 'Pairs' and others) with the synagogue, nor is there anything in early synagogue liturgy that is particularly Pharisaic."

7 On scribes and scribal culture, see most recently Chris Keith, Jesus' Literacy: Scribal Culture and the Teacher from Galilee (London: T\&T Clark, 2011), esp. 71-123, and Chris Keith, Jesus Against the Scribal Elite: The Origins of the Conflict (Grand Rapids: Baker Academic, 2014). The latter study deals more explicitly with the synagogue setting.

${ }^{8}$ We have no evidence from the first century mirroring the situation portrayed in 2 Chronicles 17:7-9, where it is stated that King Jehoshaphat sent travelling priests and Levites from Jerusalem to the cities of Judah to teach the people the law, using the "book of the Law" (v. 9; sefer Torah; LXX: byblos nomou), thus controlling the interpretation and application of the law in the land. 
universal concern in first-century Jewish society. ${ }^{9}$ Stone vessels were thought of as not susceptible to ritual impurity, and were therefore practical. It seems clear that, while it was a matter of course that purity was required before entering the Jerusalem temple, in the first century people in all parts of the land were concerned about maintaining a certain level of purity even if they were not planning to travel to Jerusalem. ${ }^{10}$ Ritual purity does not seem to have been required, though, to enter public synagogues. The miqwaoth found adjacent to such synagogues were most likely located there because it was the public place in any given town, as shown by Susan Haber. ${ }^{11}$ These synagogue buildings were, as far as the evidence can tell us, not regarded as holy space. ${ }^{12}$

Interestingly, there is evidence that some Jews understood purity to apply also to behaviour; for these Jews, moral purity could be as important or even more important than ritual purity. ${ }^{13}$ As we shall see, this approach to purity and sin will shed light on an important aspect of Matthean theology. But before we enter the narrative world of the Gospel, we need to complement and expand the discussion of first-century synagogues.

Up till now we have focussed on the institutions in which Jesus proclaimed his message of the kingdom. We have called these institutions public synagogues, and their function in towns and villages compares well with modern city halls, with an added religious dimension. But there also existed another type of institution designated by the same terms as the public synagogues, institutions which belonged to specific Jewish groups, such as the Essenes. ${ }^{14}$ In the land of Israel, we have, in addition to the Essenes, the "synagogue of the

\footnotetext{
${ }_{9}^{9}$ On stone vessels, see Ronald Deines, Jüdische Steingefäße und pharisäische Frömmigkeit (Tübingen: Mohr Siebeck, 1993); Yitzhak Magen, The Stone Vessel Industry in the Second Temple Period: Excavations at Hizma and the Jerusalem Temple Mount (Jerusalem: Israel Exploration Society, 2002); Mark A. Chancey, The Myth of a Gentile Galilee (Cambridge: Cambridge University Press, 2002), 67-68. While Deine's study is very helpful, I agree with Chancey that his thesis that the presence of stone vessels indicates Pharisaic influence is problematic. Regarding miqwaoth, see Boaz Zissu and David Amit, "Common Judaism, Common Purity, and the Second Temple Period Judean Miqwa'ot (Ritual Immersion Baths)," in Common Judaism: Explorations in Second-Temple Judaism, eds. Wayne O. McCready and Adele Reinhartz (Minneapolis: Fortress, 2008), 47-62, who conclude that "[t]he wide distribution of ritual baths reinforces Sanders's assertion that the purity laws were generally obeyed by the Jewish populations." (62). For a local-specific example, see most recently Ronny Reich and Marcela Zapata, "A Preliminary Report on the Miqwa'ot of Migdal," IEJ 64:1 (2014): 63-71. While the authors discuss the possibility of these miqwaoth serving the synagogue, they ultimately refrain from such conclusions because of the distance between the synagogue building and the miqwaoth (ca. 70 meters). Miqwaoth have been discovered adjacent to several other second-temple synagogues (the authors mention Masada, Herodium, Gamla, Jericho, Modi'in); see Ronny Reich, "The Synagogue and the Miqweh in Eretz-Israel in the Second Temple, Mishnaic and Talmudic Periods," in Ancient Synagogues: Historical Analysis and Archaeological Discovery, eds. D. Urman and P.V.M. Flesher (Leiden: Brill, 1995), 289-297. The functional relationship between synagogue and miqweh is, however, not clear. As Susan Haber, "They Shall Purify Themselves": Essays on Purity in Early Judaism, ed. Adele Reinhartz (Atlanta: Society of Biblical Literature, 2008), 161-179, has argued, it is unlikely that ritual washings were required before entering a public synagogue, as opposed to the practice in Diaspora synagogues where, judging from the archaeological remains, the washing of hands and/or feet was likely required. On various understandings of (ritual and moral) purity, see Jonathan Klawans, Impurity and Sin in Ancient Judaism (Oxford: Oxford University Press, 2000).

${ }^{10}$ Cf. John C. Poirier, "Purity Beyond the Temple in the Second Temple Era," JBL 122:2 (2003): 247-265.

11 Susan Haber, "They Shall Purify Themselves": Essays on Purity in Early Judaism, ed. Adele Reinhartz (Atlanta: Society of Biblical Literature, 2008), 161-179: "[T]he local-specific evidence pointing to the association of miquaot with synagogues appears to be spatial rather than functional” (178).

${ }^{12}$ For discussion, see Levine, Ancient Synagogue, 44, 77-79, 172; regarding later periods, see pages 200-203.

${ }^{13}$ See especially Klawans, Impurity and Sin; cf. Eyal Regev, "Moral Impurity and the Temple in Early Christianity in Light of Ancient Greek Practice and Qumranic Ideology," HTR 97:4 (2004): 383-411.

${ }_{14}$ See Philo, Prob. 80-83 (for text, translation, bibliography, and comments, see Anders Runesson, Donald D. Binder, and Birger Olsson, The Ancient Synagogue From its Origins to 200 C.E.: A Source Book, Ancient Judaism and Early Christianity Series 72 (Leiden: Brill, 2008), hereafter abbreviated $A S S B$, no. 40. Philo uses the term synagōge for the association of the Essenes, and he describes their gathering place as sacred space. For further discussion of the two types of institution referred to by synagogue terms, and their respective origins, see Runesson, Origins.
} 
Freedmen," 15 and the synagoge $\bar{e}$ mentioned in the Theodotos inscription, both institutions located in Jerusalem. ${ }^{16}$ The closest ancient analogy which may describe this type of institution is the Graeco-Roman voluntary associations, the collegia, or thiasoi. In the Diaspora, the Romans categorised synagogues together with other (non-Jewish) associations. ${ }^{17}$

Graeco-Roman associations could serve a number of different purposes, from gatherings of occupational guilds, to meetings of people sharing a common ethnic background, or worshipping the same god or goddess. Architecturally, associations often provided space for communal dining and feasting. Groups could gather in larger private houses, or in purpose-built structures adapted for larger groups. Such associations would have their own specific community rules outlining acceptable behaviour and stipulate various forms of punishment for those who did not comply with the rules. Such punishment would commonly consist of fines or, in severe cases, exclusion from the community.

In the Diaspora, Jewish associations, or association synagogues, are best understood as ethno-religious immigrant groups. Many of them were open and welcoming also of interested non-Jews (commonly termed "God-fearers," or sympathisers in the literature). ${ }^{18}$ Some, however, were more secluded and dedicated to very specific forms of Judaism, such as the Therapeutai, described at length by Philo. ${ }^{19}$ The situation in the land was similar in terms of the more open or sectarian nature of such associations, although the ethnic identity of the groups naturally did not need to be emphasised in that setting. For example, several scholars have suggested that the Dead Sea Scrolls sect belonged among the numerous voluntary associations that prospered in the Hellenistic-Roman period. ${ }^{20}$

\footnotetext{
${ }^{15}$ Acts 6:9 (ASSB, no. 18). The membership of the synagogue of the Freedmen seems to have been based on a network of people with common background.

${ }^{16} A S S B$, no. 26. The purpose of the Theodotos synagogue was to provide a place especially for pilgrims (the inscription mentions a "guest chamber" and "upper rooms," as well as water facilities for ritual washings). Most importantly, the inscription states that this synagogge was dedicated to "the reading of the law and the teaching of the commandments."

${ }^{17}$ For synagogues as a Jewish variant of Graeco-Roman associations, see especially Philip Harland, Associations, Synagogues and Congregations: Claiming a Place in Ancient Mediterranean Society (Minneapolis: Fortress, 2003), revised edition published online in 2013: http://philipharland.com/associations/ ; Peter Richardson, Building Jewish in the Roman East (Waco: Baylor University Press, 2004), esp. 207-221.

${ }_{18}$ If we are seeking modern explanatory analogies, one of the closer ones would be immigrant associations such as, e.g., the Portuguese Association of St Michael the Archangel in Hamilton, Canada. Here, we find an immigrant group who also highlights its religious identity; it is also open to visitors beyond the Portuguese community.

${ }^{19}$ Philo, Contempl. 30-33 (ASSB, no. 160). They are described as coming together for a "general assembly" (eis koinon syllogon) every seventh day; the place of meeting is described as a "sanctuary" (semneion).

${ }^{20}$ So Yonder Moynihan Gillihan, Civic Ideology, Organization, and Law in the Rule Scrolls: A Comparative Study of the Covenanters' Sect and Contemporary Voluntary Associations in Political Context (Ledien: Brill, 2011). Gillihan summarises his own work as follows: "[M]ost ancient groups appropriated patterns from the state. Comparison of the Rule Scrolls with Greco-Roman constitutional literature, as well as philosophical, rabbinic, and early Christian texts, shows that the sect's appropriation helped articulate an "alternative civic ideology" by which members identified themselves as subjects of a commonwealth alternative and superior to that of the status quo. Like other associations with alternative civic ideology, the Covenanters studied constitution and law with the intention of reform, anticipating governance of restored Israel at the End of Days." The interpretation of the Dead Sea Scrolls sectarians as a Jewish voluntary association was made earlier by Moshe Weinfeld, The Organizational Pattern and the Penal Code of the Qumran Sect: A Comparison With Guilds and Religious Associations of the Hellenistic Period (NovT et orbis antiquus 2; Göttingen: Vandenhoeck \& Ruprecht, 1986), and Mattias Klinghardt, "The Manual of Discipline in the Light of the Statutes of Hellenistic Associations," in Methods of Investigation of the Dead Sea Scrolls and the Khirbeth Qumran Site: Present Realities and Future Prospects, ed. Michael O. Wise et al. (New York: The New York Academy of Sciences, 1994), 251-267.
} 
Other groups, such as the Pharisees, were more open and were engaged in public Jewish society. ${ }^{21}$

Now, what complicates matters is that the same terms were used interchangeably for both the public synagogues and the association synagogues. The most common Greek words used were synagōge (a "gathering," or the building in which the gathering took place), proseuche ("prayer hall"), and a term that has often been mistranslated as "church": ekklessia. Ekklēsia simply means assembly, and the word was originally used in Classical Greece to designate a democratic-like institution, in which all free men had a say in the public affairs of the city. But ekklesia was also used by the Jews as a synagogue term, both for public synagogues and association synagogues. ${ }^{22}$ This means, among other things, that when ekklēsia is used in New Testament texts to designate a community of Christ-believers, we cannot draw the conclusion that they had divorced themselves from "the synagogue," or from "Judaism" as many scholars have mistakenly argued. It was not until later that the term ekklessia came to be used exclusively for what we call "church" today, and by that time, and probably as a consequence of that terminological development, mainstream Judaism had chosen "synagogue" as the sole designation for their institution.

In the first century, these terms were used interchangeably by Philo and Josephus, in inscriptions and in the New Testament as referring to either public synagogues or association synagogues. The definition of the term is thus dependent on the context in which it occurs; its meaning must be argued on a case-by-case basis. In the New Testament Gospels, synagōgē is, as we noted above, most often used for public synagogues, and ekklēsia is used three times to refer to a specific association, claimed to have been founded by Jesus himself, with Peter as the leading figure. As it happens, all three of these occurrences of the term ekklēsia are found in Matthew's Gospel, to which we now turn.23

\section{Synagogue and Community in Matthew's Narrative World}

What I would like to discuss here is not the socio-religious realties of the Matthean community, but rather the narrative world of Matthew's Gospel. We shall ask two main questions: First, how are public synagogues described, and what function do they fill in the world of the text? Second, how is the association synagogue, the ekklēsia of the Jesusfollowers, described and why is this institution so important for Matthew when none of the other Gospels mention it? Let us begin with the question of how public synagogues are used narratively as a setting for Jesus' proclamation in Matthew.

\footnotetext{
${ }^{21}$ Note the possible mention of a Pharisaic association synagogue in Matt 12:9 (discussion in Runesson, Origins, 355-357). Note also that Luke 14:1 speaks of "a leader of the Pharisees," indicating the existence of a hierarchy, which in turn reveals institutional structures, such as we would expect to find them in associations. While the evidence is scarce, other Jewish groups, such as the Sadducees and the Fourth Philosophy, all mentioned by Josephus (B.J. 2.119-166; A.J. 18.11-25; cf. A.J. 13.171-173), should be understood along similar lines as associationlike groups, since the associations provide the closest ancient analogy for such group formation.

${ }^{22}$ For literature discussing this terminology, see $n .1$ above.

${ }^{23}$ Matt 16:18; 18:17.
} 


\subsection{Public Synagogues: Eschatological Battlefields}

First we should note that, historically, any interaction in public synagogues in the first century indicates involvement in Jewish society, not withdrawal from it. This is also what we find in Matthew's story. Here, the narrator states paradigmatically, twice, that, "Jesus went throughout Galilee, teaching in their synagogues and proclaiming the good news of the kingdom and curing every disease and every sickness among the people" (Matt 4:23; cf. 9:35).

Both success and conflict is reported from encounters in this setting, and the Matthean Jesus also predicts future suffering and punishment in synagogues for his disciples (10:17; cf. 23:34). All of this describes a deep involvement in Jewish society, not only of Jesus but also of his followers, even after his death. There is no hint in the narrative of either Jesus or the movement around him leaving these institutions, and thus public Jewish society, behind. On the contrary, in the narrative, public synagogues represent public "battlefields" as the kingdom approaches. Jesus and his followers engage local Jewish towns, primarily in Galilee, healing and proclaiming what they perceive of as good news, namely that this is the time to repent and to prepare for the coming judgment and the kingdom of heaven, in which the last shall be the first, and the least shall be the greatest (Matt 19:30; 20:16; 23:12).

This involvement of the movement around Jesus in public Jewish society is quite distinct from, for example, the strategy of the sectarian community, or communities, that can be reconstructed from the Dead Sea Scrolls. These covenanters had chosen to withdraw from society and establish their own sacred community, preparing for the coming eschatological war. The Matthean Jesus and his disciples, on the contrary, are campaigning across the land in public institutions and elsewhere, clearly aiming at setting in motion a mass movement to save Israel, ${ }^{44}$ or, more precisely, to rescue the "lost sheep of the House of Israel," i.e., the people that they perceived of as abused and abandoned by their leaders (Matt 9:36). ${ }^{25}$ Since this campaign is said to be carried out in public religiopolitical institutions, where local residents gathered for various purposes related to their community, it is impossible to ignore the political implications of this "kingdom talk" that is so prominent in the Gospel. When we read Matthew in such public institutional settings we are reminded that what we separate and call "religion" and "politics" were, in antiquity, interwoven aspects of communal life.

Interestingly, the sectarians witnessed in the Dead Sea Scrolls were also very much involved in re-imagining religio-political order, and saw their vision of a just society coming to life as a result of apocalyptic end-time developments. For them, too, there could not be a distinction between "religion" and "politics"; their hopes could not, as Matthew's vision could not, be realised with less than a complete remodelling of Jewish society to bring it in line with God's intents. What differs between Jesus and the movement around him as Matthew describes it on the one hand, and these Qumran sectarians on the other, is the method they employ to achieve their (and, as they see it, the God of Israel's) goals for a

${ }^{24}$ Cf. Rom 11:26.

${ }^{25}$ Cf. Matt 15:24. 
renewed and reconstituted Israel, and, indeed, a reinvented world. ${ }^{26}$ For the Matthean Jesus' purposes and hopes, the public synagogues were key; they represented eschatological combat zones where battles were fought against inaccurate interpretations of Jewish law, which threatened to make God's people liable to the eschatological judgment, as well as against evil forces materialising as decease and illness, which were cured. ${ }^{27}$ For the sectarians, on the other hand, public Jewish society threatened to compromise their status as a pure community, "the sons of light," as they designated themselves, and they chose, consequently, to withdraw and gather in a secluded setting with little or no contact with the outside world. In the sectarian realm there were no people with disabilities, since full membership could only be given to "unblemished" individuals (mirroring the requirements for priests serving in the Jerusalem temple).

The fact that Jesus is portrayed as engaging in public synagogues may thus tell us a lot about what he, in Matthew's eyes, wanted to achieve as well as about the nature of the kingdom he worked to bring into being. It will also help us understand the Matthean Jesus' (and, in this case, I would argue the historical Jesus') relationship to other Jewish groups and public Jewish society. If we were to understand Jesus and Matthew's Gospel within the interpretive frames offered us by late-antique, or even modern synagogues or churches, i.e., by what is best termed "religious institutions," these characteristic features of Jesus' religio-political vision of and campaign for the salvation of Israel and the world would easily be lost.

Now, while the public synagogues in which Jesus is portrayed as proclaiming his message is key for our understanding of the Jewish world of Matthew's narrative, we also have, uniquely among the Gospels, references in Matthew to a separate institution, within which followers of Jesus run daily business and administer judgment: the ekklesia (Matt $16: 18 ; 18: 17)$. How should we understand this institution in relation to Jewish society? Why is such an institution necessary? Does it indicate a break with "Judaism"? The answers to such questions lie embedded in first-century Jewish understandings of purity, forgiveness, and salvation.

\subsection{The Ekklèsia: Holiness and Purity Through Forgiveness}

If we understand the public synagogues in this story as battlefields on which Jesus and his followers struggle with local scribal leaders to save the people of Israel as the kingdom advances through the land, the Matthean association synagogue, the ekklessia, represents the model for what Jewish communal life should be as people prepare for the final

\footnotetext{
${ }_{26}$ This does not mean, however, that Matthew and the Qumran sectarians would envision the same fate for those who opposed them. For Matthew, victory comes when enemies are prayed for (Matt 5:44-47) and persuaded to join them (e.g., Matt 28:18-20) during a time when Jesus' followers endure apocalyptic hardships as they await and try to embody the coming kingdom (Matt 24:7-14). For the sectarians, on the other hand, victory is envisioned as materialising when enemies, "the sons of darkness" (identified as both other, non-sectarian, Jews and non-Jews) are destroyed in an eschatological war (note the Rule of the Community [1QS], the Rule of the Congregation [1QSa], the Damascus Document [D], and the War Scroll [1QM]).

${ }_{27}$ Matt 4:23; 9:35; 12:9-13. Note that, contrary to Mark and Luke, Matthew does not report exorcisms in synagogues, although healing is, at this time, closely related to a world of ideas in which illness is a physical sign of the power of evil forces. On illness and disability as connected with the work of demons and cured through exorcisms in Matthew, as well as such incidents' relationship to the coming of God's kingdom, see Matt 12:22-28.
} 
judgment and the full realisation of the kingdom that will follow. But what exactly is the nature of this association?

As with other associations, such as the Qumran sectarians, the Matthean eschatologically oriented ekklessia provides a separate institutional setting for its members, in which they form and make decisions about their own communal life. This institution has its own "judicial system," which is independent of the praxis of the courts housed in the public synagogues; it exists beyond public civic ideology and represents practices founded on interpretations of Jewish law that have been agreed upon within the group itself. ${ }^{28}$ The "alternative civic ideology" and the community rule that was formulated based on it allowed this messianic group to punish with exclusion members who broke the rules. ${ }^{29}$

The rules of the ekklesia are described briefly and selectively in Matthew's $18^{\text {th }}$ chapter, but the full picture emerges only when the narrative is read in its entirety. In order to describe the nature and function of the Matthean ekklessia and its rules for exclusion we need to first understand the dynamics of holy and profane, of pure and impure, in the Gospel. These concepts and the narrative reality that they create lie at the heart of Matthew's Gospel. As we shall see, while there are many studies of the "ethics" of, e.g., the Sermon on the Mount, or Matthew's Gospel as a whole, labelling what we see in Matthew "ethics" may lead the twenty-first-century reader astray. Instead, we should approach the narrative and its rules through the lens of ritual and, most importantly, moral impurity. We shall begin with the problem of holiness.

In Matthew's narrative, the only place and the only institution explicitly described as holy are the city of Jerusalem and the Jerusalem temple and its altar. ${ }^{30}$ Before Matthew's twenty-third chapter, the temple cult, which can only be carried out in this holy place, is considered valid and must be protected from defilement. ${ }^{31}$ Defilement, for Matthew, comes primarily from moral impurity, since ritual purity is considered worthless if the weightier matters of the law, that is, the moral commandments, are neglected. ${ }^{32}$ This is noted explicitly several times in the Gospel, most clearly in Matt 15:18-20:

\footnotetext{
${ }_{28}$ Matt 16:19; 18:18.

${ }^{29}$ Matt 18:17. While Matthew's Gospel cannot have functioned as a community rule (it is a different genre, presenting the life of Jesus in narrative form), we have an example of a community rule used in communities which most likely also used Matthew's Gospel: the Didache. For a recent discussion of the Didache and its relationship to the Gospel of Matthew (and the Letter of James), see Huub van de Sandt and Jürgen Zangenberg, eds., Matthew, James, and the Didache: Three Related Documents in Their Jewish and Christian Settings (Atlanta: Society of Biblical Literature, 2008). See also Huub van de Sandt and David Flusser, The Didache: Its Jewish Sources and its Place in Early Judaism and Christianity (Assen: Royal Van Gorcum, 2002). For the argument that the Didache should be understood as the community rule used in communities also using the Gospel of Matthew, see also Anders Runesson, "Building Matthean Communities: The Politics of Textualization," in Mark and Matthew. Comparative Readings I: Understanding the Earliest Gospels in their First-Century Setting(s), eds. Eve-Marie Becker and Anders Runesson (Tübingen: Mohr Siebeck, 2011), 379-408.

${ }^{30}$ Regarding Jerusalem, see Matt 4:5; 23:16-17; 27:53. The temple's holiness is noted in 24:15, and the sacred status of the altar is implied in 5:23-24, cf. 23:18-19. On the status of the Jerusalem temple in Matthew's Gospel, see Daniel M. Gurtner, "Matthew's Theology of the Temple and the 'Parting of the Ways': Christian Origins and the First Gospel," in Built Upon the Rock: Studies in the Gospel of Matthew, eds. Daniel M. Gurtner and John Nolland (Grand Rapids: Eerdmans, 2008), 128-153.

${ }^{31}$ Matt 5:23-24.

${ }^{32}$ Matt 23:23. See discussion in Anders Runesson, "Purity, Holiness, and the Kingdom of Heaven in Matthew's Narrative World," in Purity and Holiness in Judaism and Christianity: Essays in Memory of Susan Haber, eds. Carl Ehrlich, Anders Runesson, and Eileen Schuller (Tübingen: Mohr Siebeck, 2013), 144-180.
} 
But what comes out of the mouth proceeds from the heart, and this is what defiles. For out of the heart come evil intentions, murder, adultery, fornication, theft, false witness, slander. These are what defile a person.

In chapters 23-24, however, something happens, and here we find the centre of gravity in Matthew's message: the temple, which is holy, has been defiled by the leaders of the people. ${ }^{33}$ The severity of the defilement - bloodshed, one of the worst sources of moral defilement in Jewish tradition, is mentioned explicitly as having taken place within the temple itself ${ }^{4}$ - leads to God leaving the temple (cf. 23:38), just as God left the first temple before its destruction as described in Ezekiel 10-11. In Matthew, this happens in two steps. First, God's Messiah, Jesus, leaves for the Mount of Olives, which is also where Ezekiel had "God's Glory [kevod Adonay]" stay after God left the first temple. ${ }^{35}$ Second, the moment when the Messiah dies as a result of the cooperation between the high priests and the elders of Jerusalem on the one hand, and the Roman colonial powers on the other, the temple curtain is ripped apart, symbolising God's abandonment of the temple and its impending destruction: "At that moment the curtain of the temple was torn in two, from top to bottom."36

Matthew's theological logic, which is thoroughly embedded in Jewish tradition, thus develops as follows. God chose Israel and established the covenant with them in order to enable God's presence to be among the people. The Mosaic law, which includes the means of atonement provided by the temple cult, was given for this purpose, and a place, the Jerusalem temple, was set aside as holy enabling God to be present among the people. As long as God lives in the temple, the temple cannot be destroyed, but if the temple is defiled, for example by bloodshed, God cannot remain there since holiness cannot co-exist with impurity. ${ }^{37}$ With the temple defiled and eventually destroyed (24:1-2), there remains no means of atonement and the Mosaic covenant breaks down; the law cannot function, in Second-Temple Judaism, in isolation from the means of atonement embedded within it.

This is precisely why Jesus has to die according to Matthew: to save his people from their $\sin ,{ }^{38}$ by way of eschatologically restoring the Mosaic covenant through his sacrifice

\footnotetext{
33 The people accused are here, unhistorically, identified as Pharisees and the scribes associated with them.

34 Matt 23:29-36; note v. 35.

35 Ezek 11:23.

${ }_{36}$ Matt 27:51. Cf. the prediction in Matt 23:38: "See, your house [i.e., the temple] is left to you, desolate." On the tearing of the temple curtain and its interpretation, including discussion of the temple veil in Second-Temple and Rabbinic literature, see Daniel M. Gurtner, The Torn Veil: Matthew's Exposition of the Death of Jesus (Cambridge: Cambridge University Press, 2007).

${ }^{37}$ Cf. Josephus, J.W. 6.127, 300, where God leaves the temple before its destruction (cf. A.J. 10.165-167; J.W., 2.254-257). On Josephus and purity, see Steve Mason, "Pollution and Purification in Josephus's Judean War," in Purity and Holiness in Judaism and Christianity: Essays in Memory of Susan Haber, eds. Carl Ehrlich, Anders Runesson, and Eileen Schuller (Tübingen: Mohr Siebeck, 2013), 181-207. Later, the rabbis combined bloodshed and hatred as they explained the destruction of the first and the second temple respectively; see $b$. Yoma $9 \mathrm{~b}$. This passage makes explicit that "baseless hatred" is equalled to the worst of sins: bloodshed, sexual immorality, and idolatry. It should be noted that guilt for the destruction of the Temple is always sought, in the Hebrew Bible and Josephus, as well as in rabbinic literature and the New Testament Gospels, within the Jewish people. The (theological) reason for this is that if someone else, such as the Romans, would be accused, their god(s), by implication, would have to be judged stronger than the God of Israel, who would then have been shown to lack the power needed to defend his own abode. By blaming the Jewish leadership (the Gospels), or Jewish "bandits" (Josephus), the Romans are transformed into a tool in the hand of the God of Israel as he punishes his people. This strengthens the view that the Gospels were written by Jews from an inner-Jewish perspective, even if they were meant to be read also by a non-Jewish audience.
}

${ }^{38}$ Matt 1:21. 
(i.e., his death, described as a voluntary sacrificial offering), which brings atonement, as reported in the passage of the Last Supper. ${ }^{39}$ Jesus' sacrifice is thus necessary for the people of Israel to survive the apocalyptic end-time suffering and the final judgment. ${ }^{40}$ Since the time of the patristic authors until today, Christian thinkers have often construed the destruction of the temple as God's punishment for the death of Jesus. From Matthew's perspective, however, it is the other way around: Because the temple will be destroyed, based on the fact that it has already been defiled (Matt 23:37-24:2), Jesus has to sacrifice himself to save his people. ${ }^{41}$

None of this means that Jerusalem and the temple have ceased to be holy for Matthew. The temple has been defiled, yes, but this view in fact requires that the defiled space has a remaining quality that distinguishes it from all other space; the temple after Matthew's twenty-third chapter does not represent ordinary profane space, but defiled holy space, and as such it is unfit for God's presence. But, if Jesus' sacrifice is understood as restoring the Mosaic covenant and saving God's people, where then, if not in the defiled and soonto-be-destroyed temple, is God's presence to reside? This is where the ekklessia, with its centre in Galilee (28:10), emerges in the narrative as a key institution for the Jewish people until the final judgment, since the community that gathers around Jesus now comes to represent the holy space where the resurrected Jesus, in a manner that is reminiscent of the Shekhinah dwelling among the people of Israel, can be present (Matt $18: 20) \cdot{ }^{4}$

An important function of the ekklesia is to provide access to a "space" where the divine may be approached once the temple has become defiled. This institution represents the place where true instruction in the Mosaic law and halakhah ${ }^{43}$ is given among equals, ${ }^{44}$ so that the people can avoid condemnation in the final judgment (cf. Matt 7:21). In the ekklesia, most importantly, people will find access to the means of atonement ${ }^{45}$ necessary for the law to function within the covenant. Since, however, the presence of the divine among the people requires purity, and the resurrected Jesus' presence among those who follow his guidance seems to be portrayed as being on par with that of the shekhinah, this

\footnotetext{
${ }^{39}$ Matt 26:26-28.

${ }^{40}$ Cf. Matt 24:1-36.

${ }_{41}$ This also means that those who are blamed for the fall of the temple, i.e., the Pharisees and the scribes associated with them, are, in the narrative, the real reason why Jesus has to die, and so they turn into the Matthean Jesus' worst enemies. (The portrayal of the Pharisees in the other Gospels, esp. in Luke, is much more varied, with both positive and negative examples described. Indeed, in Luke 13:31, we even find Pharisees trying to save Jesus' life when Herod Antipas wants to kill him.)

42 The interpretive dynamics in Matthew are similar, thus, to those that are found in the Dead Sea Scroll; the sectarians, too, construed their community as sacred space functioning as a substitute for what they understood as a non-functioning Jerusalem temple. Paul, too, speaks of followers of Jesus as temple space; cf. n. 51 below.

${ }^{43}$ Matt 16:19; 18:18. In terms of interpretation of Mosaic law, much of the Gospel is dedicated to this theme. Overall instruction is, paradigmatically, given in the Sermon on the Mount (Matthew 5-7), and we get a summary of the law and the prophets in Matt 7:12. That Moses and the prophets would support Jesus' authoritative interpretation of the law is clarified in Matt 17:3 (where Elijah represents the Prophets). Various examples of Jesus' specific halakhic decisions are given throughout the narrative (e.g., 19:3-9, 17-19; 23:16-23) and the hermeneutical core which should guide all interpretation of Torah and form the foundation for halakhic decisions is explicated in Matt 22:36-40, referring to Deut 6:5 and Lev 19:18.

${ }^{44}$ Matt 23:8-12. Note that this instruction is given not only to the disciples but to the Jewish "crowds" (hoi ochloi) too (23:1). In Matthew, there is no distinct boundary between the disciples and the crowds, the latter representing the majority of the Jewish people, excluding the leadership groups. This reinforces the point made above, that Jesus' followers were active in public Jewish society not only around Jesus' time in the 30s, but also as late as when the Gospel was authored in the late first century.

${ }^{45}$ I.e., Jesus' sacrifice, re-enacted as a ritual meal; Matt 26:26-28.
} 
means that purity will be required for the members of the ekklesia in order for the resurrected to be present among them. This last point needs some elaboration.

As has been noted above, Matthew's narrative emphasises that purity must first and foremost be defined as moral purity (e.g., Matt 15:18-20). This in turn means that to uphold a state of purity, forgiveness ${ }^{46}$ becomes crucial, since no person can produce perfect obedience to the law in this regard and "perfection" is required. ${ }^{47}$ We see this interpretive dynamic already in the Sermon on the Mount, when Jesus protects the holiness of the temple by ruling that a person who has committed a sin against someone else has to reconcile with that person before approaching the altar; once reconciliation is in place, sacrifices are acceptable and can be offered. Forgiveness and reconciliation between people neutralises, as it were, the defilement that attaches to the person who sins and allows the person to approach the holy..$^{48}$ The removal of moral impurity requires, thus, a two-step procedure, one involving fellow human beings, and one in which the divine is approached. For the latter to be possible the former must have been accomplished (cf. Matt 6:12, 14-15), since one cannot approach the divine in a state of (moral) defilement. Without forgiveness and reconciliation between humans, then, God cannot dwell among the people.

This theological logic is applied to the ekklēsia, as the "space" where the resurrected promises to be present, in Matthew 18. Here, as the community rule is exemplified through a focus on its exclusion mechanism, we learn that a person who refuses to ask for forgiveness must be excluded from the ekklēsia and be regarded as a non-Jew (ethnikos) or a tax collector; that is, as people either understood to be outside the covenant based on their ethnic identity (and the inappropriate behaviour that for Matthew is associated with the nations), ${ }^{49}$ or as Jews who fail to live up to the standards of the kingdom through their cooperation with those who contribute to the oppression of the common people (Matt 18:17). Both of these categories of people represent what it means to be (morally) impure. The boundary of the community is thus drawn sharply where forgiveness ends, and this preserves the (moral) purity of its members, allowing Jesus' presence in their midst (Matt 18:20). The message is further reinforced as Jesus instructs the foundational figure of the ekklessia, Peter, to forgive indefinitely anyone who asks for forgiveness (Matt 18:21-35). ${ }^{50}$

${ }^{46}$ On forgiveness as understood in antiquity, see the recent studies by David Konstan, Before Forgiveness: The Origins of a Moral Idea (Cambridge: Cambridge University Press, 2010), and Charles L. Griswold and David Konstan, eds., Ancient Forgiveness: Classical, Judaic, and Christian (Cambridge: Cambridge University Press, 2012).

${ }_{47}$ Note Matt 5:48, which sums up a section of halakhic rulings: "Be perfect [teleios], therefore, as your heavenly Father is perfect." The connection between perfection and holiness is implied in the allusion Lev 19:2. On perfection, see also Matt 19:21.

${ }^{48}$ See discussion in Runesson, "Purity, Holiness, and the Kingdom of Heaven," 169-171. See also Anders Runesson, Divine Wrath and Salvation in Matthew (Minneapolis: Fortress, forthcoming).

${ }_{49}$ According to Matthew, non-Jews represent, when generalised, everything that a good Jew should avoid (e.g., Matt 5:47;6:7;19:25-26). The positive portrayal of some individual non-Jews (e.g., Matt 2:1-12; 8:5-13; 15:21-28) are exceptions, functioning primarily as rhetorical tools to shame those within the Jewish people who do not accept that Jesus is inaugurating the kingdom. These non-Jewish characters also provide an opportunity for Matthew to reinforce that the proper attitude of non-Jews in relation to the Jewish Messiah is subordination; when they accept the power of the Messiah they will receive a share of the blessings of the kingdom, even as non-Jews.

${ }_{50}$ Cf. 6:12, 14-15. Without inter-human forgiveness there will be no reconciliation between God and people. It should be added that if someone refuses to forgive, and thus binds the other person in his or her sin, there is still a way out for that person. In such cases, Jesus himself steps in and extends, vicariously, forgiveness to the repentant sinner. See discussion of this aspect of Matthew's theology of forgiveness, illustrated by the story in Matt 9:1-8, in Runesson, "Purity, Holiness, and the Kingdom of Heaven," 171. The fate of the unforgiving party is, however, irreversible: condemnation (cf. Matt 18:34-35). 
Once the nature and function of the ekklēsia is understood as a community, an institution, providing holy "space" as the eschaton and its related liberation is fast approaching - protecting its members as the Israelites were once protected in Egypt by the blood of a lamb when God's wrath was unleashed against Pharaoh - the importance of forgiveness between its members emerges as a logical extension of a Jewish theology of the sacred. Just as with the sectarians at Qumran, but with a very different understanding of the end-time requirements, the Matthean association, the ekklēsia, aims at gathering a reformed and pure Israel, prepared for the coming judgment. ${ }^{51}$ Its members anticipate a restored Israel in a recreated world, which is headed by their messiah and the twelve apostles, representing the twelve tribes. ${ }^{52}$ In this world, which will also consist of non-Jews who have joined them, 53 "the righteous will shine like the sun in the kingdom of their Father." ${ }^{54}$

\section{Conclusion: Understanding Matthew as a Jewish Text}

Understanding Matthew's Narrative from the perspective of the institutional settings it describes results in a sharper focus on the Jewish nature of the world of the text. The Matthean Jesus and his followers are described as passionately engaging the public Jewish society of which they themselves are a part, and their message emerges, within these religio-civic institutions, as politically charged. Jesus and his disciples are presented as initiating a mass movement which aims at the liberation of the people of Israel through acting as tools of God's Spirit, wrestling religio-political power from the hands of the scribal elite in public synagogues and the chief priests and the elders in the Jerusalem temple.

This scenario, I would argue, closely resembles what we should expect to find in a reconstruction of the historical Jesus. But Matthew adds to this depiction of the early movement a fierce critique of a specific group, the Pharisees, which had no official power in public Jewish society, neither in the synagogues nor in the temple. I have argued elsewhere, referring to insights not least from the social sciences, that this curious narrative situation, unique among the Gospels, can be explained if we reconstruct the group producing the Gospel as involved in a parting of the ways process within a larger Pharisaic association. ${ }^{55}$ In the world of the text, we see the followers of Jesus interacting in

\footnotetext{
${ }^{51}$ Note also how Paul construes his ekklesiai as sacred (temple) space, imagery which implies the necessity of purity. See e.g., 1 Cor $3: 16-17 ; 6: 19 ; 2$ Cor $6: 16$. Paul, too, demands that people who are (morally) impure must be excluded from the community (e.g., 1 Cor 5:11-13; cf. 6:9-11). For discussion of purity in Paul's writings, see Cecilia Wassen, "Do you have to be Pure in a Metaphorical Temple? Sanctuary Metaphors and Construction of Sacred Space in the Dead Sea Scrolls and Paul's Letters," in Purity and Holiness in Judaism and Christianity: Essays in Memory of Susan Haber, eds. Carl Ehrlich, Anders Runesson, and Eileen Schuller (Tübingen: Mohr Siebeck, 2013), 55-86. The temple as the presence of God among the people, and thus among the community of Christ-believers, is emphasised in 2 Cor 6:16-7:1.

${ }_{52}$ Matt 19:28.

${ }^{53}$ Cf. Matt 28:18-20.

${ }^{54}$ Matt 13:43.

${ }^{55}$ Anders Runesson, "Re-Thinking Early Jewish-Christian Relations: Matthean Community History as Pharisaic Intragroup Conflict," JBL 127:1 (2008): 95-132. Note that the Pharisees is the only Jewish group mentioned in the sources as giving birth to Christ-believers. Paul may be the most well-known example, as he is portrayed in Acts as combining a Pharisaic identity with his identity as a follower of Jesus (Acts 23:6). Of course, we also have the Pharisaic Christ-believers mentioned in Acts 15:5, whose view on the circumcision of non-Jews who wanted to join the Jesus movement was rejected by the leaders of the movement in Jerusalem.
} 
public Jewish society but also as founding a new association, the ekklessia; the latter process in no way interferes with the former, and does not lead to, as in the case with the Sectarians by the Dead Sea, a withdrawal from society and other Jewish groups. The Pharisees in Matthew are attacked as a group existing on the same social level as the ekklessia, also interacting with other Jews in public settings. The Jesus movement is portrayed as aiming to win over to their side the crowds, having them joining the ekklesia and in this way, through proper teaching of law and the provision of a mechanism of atonement, saving the people from condemnation in the final judgment (cf. Matt 1:21).

Within this institutional setting, which foreshadows the coming kingdom and establishes what is required of the people if they are to enter life in the restored Israel where God will be present, (moral) purity is crucial since the resurrected will be among them as they await and prepare for the end (cf. Matt 1:23; 18:20). As Eyal Regev has noted, ideas and practices related to the concept of moral purity lies at the heart of what developed into Christian ethics. ${ }^{56}$ I would add that using the word "ethics" when discussing the Gospel of Matthew, and, as is so common, the Sermon on the Mount, leads us astray since it makes us think of ideas and behaviour as detached from the realm of cultic practices and concepts. In Matthew, as in other forms of first-century Judaism, what we tend to label as cult and ethics were inextricably intertwined due to the purity concerns that exist at the centre of both, concerns whose aim it was to enable the God of Israel to dwell among the people.

While Matthew's Gospel is included in the Christian canon and we therefore tend to think about this text as "Christian," such a designation is, arguably, a misnomer. What developed into the phenomenon we know as mainstream "Christianity" is a form of nonJewish religion that did not exist in the first century. A historical reading of Matthew's Gospel should lead to, in my opinion, designating this text as a first-century Jewish text, regardless of its later reception; after all, few would call the texts included in the Hebrew Bible "Christian" despite the fact that they were appropriated by Christianity and made part of the Christian canon. The institutional and theological dynamics of Matthew function well when read within first-century Jewish socio-theological and cultic logic, but collapse when read in late-antique Christian settings.

Such historical results may cause some anxiety among modern mainstream Christian and Jewish communities, since they tend to blur the boundaries that were established between these religions in late antiquity, and which have since, by and large, remained in place. The historian's task is, however, not to confirm later normative developments but to search for voices and landscapes that have been lost. These voices may not always suit our contemporary narratives and claims - they may even challenge them - but the hermeneutical burden of making them useful today, regardless of what we mean by useful, lies, after all, not with the ancients but with us. We must resist, as historians, the temptation to colonise the past with our own perspectives, which in the end can do little more than serve our own identity needs. Exploring Matthew's narrative world as it prepares for the coming kingdom ideally should bring us closer to the historical "other." This "otherness" that we encounter may contribute to putting ourselves and our identities in perspective and help us understand historical developments beyond normative narratives. In my opinion, this is not only a worthwhile historical exercise; it is also a

\footnotetext{
${ }^{56}$ Regev, "Moral Impurity and the Temple in Early Christianity."
} 
hermeneutical exercise that may lead to a greater understanding of the contemporary world and the interaction between Jews and Christians within it.

\section{ABBREVIATIONS}

ASSB: Runesson, Anders, Donald D. Binder, and Birger Olsson.

The Ancient Synagogue From its Origins to 200 C.E.: A Source Book.

Ancient Judaism and Early Christianity Series 72. Leiden: Brill, 2008.

ConBNT: Coniectanea biblica, New Testament

HTR: Harvard Theological Review

IEL: Israel Exploration Journal

JBL: Journal of Biblical Literature

NovT: Novum Testamentum

\section{BIBLIOGRAPHY}

Chancey, Mark A. The Myth of a Gentile Galilee. Cambridge: Cambridge University Press, 2002.

Cohen, Shaye J.D. "The Place of the Rabbi in Jewish Society." In The Galilee in Late Antiquity, edited by Lee I. Levine; New York, 157-173. The Jewish Theological Seminary of America, 1992.

Deines, Ronald. Jüdische Steingefäße und pharisäische Frömmigkeit. Tübingen: Mohr Siebeck, 1993.

Gillihan, Yonder Moynihan. Civic Ideology, Organization, and Law in the Rule Scrolls: A Comparative Study of the Covenanters' Sect and Contemporary Voluntary Associations in Political Context. Leiden: Brill, 2011.

Griswold, Charles L., and David Konstan, eds. Ancient Forgiveness: Classical, Judaic, and Christian. Cambridge: Cambridge University Press, 2012.

Gurtner, Daniel M. "Matthew's Theology of the Temple and the 'Parting of the Ways': Christian Origins and the First Gospel." In Built Upon the Rock: Studies in the Gospel of Matthew, edited by Daniel M. Gurtner and John Nolland, 128-153. Grand Rapids: Eerdmans, 2008.

- The Torn Veil: Matthew's Exposition of the Death of Jesus. Cambridge: Cambridge University Press, 2007.

Haber, Susan. "They Shall Purify Themselves": Essays on Purity in Early Judaism, edited by Adele Reinhartz. Atlanta: Society of Biblical Literature, 2008.

Harland, Philip. Associations, Synagogues and Congregations: Claiming a Place in Ancient Mediterranean Society. Minneapolis: Fortress, 2003. Revised edition published online 2013: http://philipharland.com/associations/

Keith, Chris. Jesus Against the Scribal Elite: The Origins of the Conflict. Grand Rapids: Baker Academic, 2014.

- Jesus' Literacy: Scribal Culture and the Teacher from Galilee. London: T\&T Clark, 2011. 
Klawans, Jonathan. Impurity and Sin in Ancient Judaism. Oxford: Oxford University Press, 2000.

Klinghardt, Mattias. "The Manual of Discipline in the Light of the Statutes of Hellenistic Associations." In Methods of Investigation of the Dead Sea Scrolls and the Khirbeth Qumran Site: Present Realities and Future Prospects, edited by Michael O. Wise, Norman Golb, John J. Collins, and Dennis G. Pardee, 251-267. New York: The New York Academy of Sciences, 1994).

Konstan, David. Before Forgiveness: The Origins of a Moral Idea. Cambridge: Cambridge University Press, 2010.

Korner, Ralph. "Before 'Church': Political, Ethno-Religious and Theological Implications of the Collective Designation of Pauline Christ-Followers as Ekklesiai." Ph.D thesis, McMaster University, 2014.

Levine, Lee I. The Ancient Synagogue: The First Thousand Years. New Haven: Yale University Press, 2005.

"The Sages and the Synagogue in Late Antiquity." The Galilee in Late Antiquity, edited by Lee I. Levine, 201-224. New York: The Jewish Theological Seminary of America, 1992.

Magen, Yitzhak. The Stone Vessel Industry in the Second Temple Period: Excavations at Hizma and the Jerusalem Temple Mount. Jerusalem: Israel Exploration Society, 2002.

Mason, Steve. "Pollution and Purification in Josephus's Judean War." In Purity and Holiness in Judaism and Christianity: Essays in Memory of Susan Haber, edited by Carl Ehrlich, Anders Runesson, and Eileen Schuller, 181-207. Tübingen: Mohr Siebeck, 2013.

Poirier, John C. "Purity Beyond the Temple in the Second Temple Era." JBL 122:2 (2003): 247-265

Regev, Eyal. "Moral Impurity and the Temple in Early Christianity in Light of Ancient Greek Practice and Qumranic Ideology.” HTR 97:4 (2004): 383-411.

Reich, Ronny, and Marcela Zapata. "A Preliminary Report on the Miqwa'ot of Migdal." IEJ 64:1 (2014): 63-71.

"The Synagogue and the Miqweh in Eretz-Israel in the Second Temple, Mishnaic and Talmudic Periods." In Ancient Synagogues: Historical Analysis and Archaeological Discovery, edited by D. Urman and P.V.M. Flesher, 289-297. Leiden: Brill, 1995.

Richardson, Peter. Building Jewish in the Roman East. Waco: Baylor University Press, 2004.

Runesson, Anders. "Building Matthean Communities: The Politics of Textualization." In Mark and Matthew. Comparative Readings I: Understanding the Earliest Gospels in their First-Century Setting(s), edited by Eve-Marie Becker and Anders Runesson, 379408. Tübingen: Mohr Siebeck, 2011.

Divine Wrath and Salvation in Matthew. Minneapolis: Fortress, forthcoming.

"The Historical Jesus, the Gospels, and First-Century Jewish Society: The Importance of the Synagogue for Understanding the New Testament." In A City Set on a Hill: Essays in Honour of James F. Strange, edited by Daniel A. Warner and Donald D. Binder, 265-297. Mountain Home, AR: BorderStone Press, LLC, 2014.

"Inventing Christian Identity: Paul, Ignatius, and Theodosius I." In Exploring Early Christian Identity, edited by Bengt Holmberg, 59-92. Tübingen: Mohr Siebeck, 2008. 
. The Origins of the Synagogue: A Socio-Historical Study. ConBNT 37. Stockholm: Almqvist \& Wiksell International, 2001.

"Paul's Judaism: The Architecture of Contemporary Discussions." In Paul within Judaism: Restoring the First-Century Context to the Apostle, edited by Mark Nanos and Magnus Zetterholm. Minneapolis: Fortress, 2015.

_ . "Purity, Holiness, and the Kingdom of Heaven in Matthew's Narrative World." In Purity and Holiness in Judaism and Christianity: Essays in Memory of Susan Haber, edited by Carl Ehrlich, Anders Runesson, and Eileen Schuller, 144-180. Tübingen: Mohr Siebeck, 2013.

. "Re-Thinking Early Jewish-Christian Relations: Matthean Community History as Pharisaic Intragroup Conflict.” JBL 127:1 (2008): 95-132.

Runesson, Anders, Donald D. Binder, and Birger Olsson. The Ancient Synagogue From its Origins to 200 C.E.: A Source Book. Ancient Judaism and Early Christianity Series 72. Leiden: Brill, 2008.

Sandt, Huub van de, and David Flusser, The Didache: Its Jewish Sources and its Place in Early Judaism and Christianity. Assen: Royal Van Gorcum, 2002.

Sandt, Huub van de, and Jürgen Zangenberg, eds. Matthew, James, and the Didache: Three Related Documents in Their Jewish and Christian Settings. Atlanta: Society of Biblical Literature, 2008.

Spigel, Chad S. Ancient Synagogue Seating Capacities: Methodology: Analysis and Limits. Tübingen: Mohr Siebeck, 2012.

Stemberger, Günter. Jews and Christians in the Holy land: Palestine in the Fourth Century. Edinburgh: T \& T Clark, 2000.

Strange, James F. "Archaeology and Ancient Synagogues up to about 200 CE." In The Ancient Synagogue: From its Origins until $200 \mathrm{CE}$, edited by Birger Olsson and Magnus Zetterholm, 37-62. Stockholm: Almqvist \& Wiksell International, 2003.

Wassen, Cecilia. "Do you have to be Pure in a Metaphorical Temple? Sanctuary Metaphors and Construction of Sacred Space in the Dead Sea Scrolls and Paul's Letters." In Purity and Holiness in Judaism and Christianity: Essays in Memory of Susan Haber, edited by Carl Ehrlich, Anders Runesson, and Eileen Schuller, 55-86. Tübingen: Mohr Siebeck, 2013.

Weinfeld, Moshe. The Organizational Pattern and the Penal Code of the Qumran Sect: A Comparison With Guilds and Religious Associations of the Hellenistic Period. NovT et orbis antiquus 2. Göttingen: Vandenhoeck \& Ruprecht, 1986.

Zissu, Boaz, and David Amit. "Common Judaism, Common Purity, and the Second Temple Period Judean Miqwa'ot (Ritual Immersion Baths).” In Common Judaism: Explorations in Second-Temple Judaism, edited by Wayne O. McCready and Adele Reinhartz, 47-62. Minneapolis: Fortress, 2008. 